\title{
Level Larutan McDougall dan Asal Cairan Rumen pada Teknik In Vitro
}

\author{
Levels of McDougall Solution and the Origin of Rumen Fluid on In Vitro Techniques \\ N. Suningsih", S. Novianti" ${ }^{* *}$ dan J. Andayani"** \\ *Fakultas Pertanian, Prodi Peternakan Universitas Musi Rawas \\ **Fakultas Peternakan Universitas Jambi \\ Jl. Komplek Perkantoran Pemkab Mura Kel Air Kuti I Kota Lubuklinggau \\ e-mail: ninings412@gmail.com
}

\begin{abstract}
This porpose of this study was to determine the effect of various levels of McDougall solution, the origin of rumen fluid, and a combination of various levels McDougall solution with origin of rumen fluid on the dry matter, organic matter and crude protein in vitro. This study used completely randomized factorial design with six treatments and four replications. Such treatments include: A1B1 $=2: 1(26.67 \mathrm{ml}$ McDougall: $13.33 \mathrm{ml}$ cow's rumen fluid), A1B2 = 2: 1 (26.67 ml McDougall : $13.33 \mathrm{ml}$ rumen fluid buffalo), A2B1 = $3: 1(30 \mathrm{ml}$ McDougall : $10 \mathrm{ml}$ of liquid cow's rumen), A2B2 $=3: 1$ (30 ml McDougall : $10 \mathrm{ml}$ rumen fluid buffalo), A3B1 $=4: 1(32 \mathrm{ml}$ McDougall $: 8 \mathrm{ml}$ of liquid cow's rumen $)$, A3B2 $=4: 1(32 \mathrm{ml}$ McDougall $: 8 \mathrm{ml}$ rumen fluid buffalo). The parameters observed in this study is the dry matter digestibility (KcBK), organic matter digestibility (KcBO), and digestibility of crude protein (KcPK). The results of this study indicated that the use of the combination between the McDougall solution and the origin of rumen fluid was not significant $(\mathrm{P}>0,05)$ on the dry matter digestibility $(\mathrm{KcBK})$ and organic materials $(\mathrm{KcBO})$ but McDougall solution level factors (factor A) affected significantly $(\mathrm{P}<0.05)$ on digestibility of crude protein $(\mathrm{KcPK})$. The conclusion of this study is the use of various levels McDougall solution that combined well with rumen cow fluid and buffalo rumen fluid indicates dry matter and organic digestibilities are relatively the same. However on level $2: 1$ significant effect was higher on the digestibility of crude protein.
\end{abstract}

Key words : levels, McDougall, rumen fluid, in vitro

\begin{abstract}
ABSTRAK
Penelitian ini bertujuan untuk mengetahui pengaruh berbagai level larutan McDougall, asal cairan rumen, dan kombinasi berbagai level larutan McDougall dengan asal cairan rumen terhadap kecernaan bahan kering, bahan organik, dan protein kasar secara in vitro. Penelitian ini menggunakan Rancangan Acak Lengkap Faktorial dengan enam perlakuan dan empat ulangan. Perlakuan tersebut meliputi: A1B1 $=2: 1 \quad(26,67 \mathrm{ml}$ larutan McDougall : 13,33 ml cairan rumen sapi), A1B2 = 2:1 (26,67 ml larutan McDougall : 13,33 ml cairan rumen kerbau), A2B1 = 3:1 (30 ml larutan McDougall : $10 \mathrm{ml}$ cairan rumen sapi), A2B2 = 3:1 (30 ml larutan McDougall : $10 \mathrm{ml}$ cairan rumen kerbau), A3B1 $=4: 1$ (32 ml larutan McDougall $: 8 \mathrm{ml}$ cairan rumen sapi), A3B2 $=4: 1(32 \mathrm{ml}$ larutan McDougall $: 8 \mathrm{ml}$ cairan rumen kerbau $)$. Peubah yang diamati dalam penelitian ini adalah kecernaan bahan kering (KcBK), kecernaan bahan organik (KcBO), dan kecernaan protein kasar (KcPK).Hasil penelitian ini menunjukkan bahwa penggunaan kombinasi antara larutan McDougall dan asal cairan rumen tidak berpengaruh nyata $(\mathrm{P}>0,05)$ terhadap kecernaan bahan kering $(\mathrm{KcBK})$ dan bahan organik $(\mathrm{KcBO})$ namun faktor level larutan McDougall (Faktor A) berpengaruh nyata $(\mathrm{P}<0,05)$ terhadap kecernaan protein kasar (KcPK). Kesimpulan dari penelitian ini adalah penggunaan berbagai level larutan McDougall yang dikombinasikan baik dengan cairan rumen sapi maupun cairan rumen kerbau menunjukkan kecernaan bahan kering dan bahan organik yang relatif sama. Namun pada level $2: 1$ memberikan pengaruh yang nyata lebih tinggi terhadap kecernaan protein kasar.
\end{abstract}

Kata Kunci : level, McDougall, cairan rumen, in vitro

\section{PENDAHULUAN}

Dalam mengevaluasi kecernaan suatu bahan pakan ada banyak teknik yang digunakan, diantaranya adalah teknik in vivo, teknik in sacco, dan teknik in vitro. Teknik in vivo adalah teknik pengukuran nilai kecernaan suatu bahan pakan secara 
langsung yaitu langsung diujikan kepada ternak, teknik in sacco adalah teknik pengukuran nilai kecernaan suatu bahan pakan dengan menggunakan kantong nilon, sedangkan teknik in vitro adalah teknik pengukuran nilai kecernaan suatu bahan pakan dengan cara menguji bahan pakan tersebut di dalam tabung fermentor yang memiliki kondisi seperti pada lambung ruminansia.

Kelebihan penentuan kecernaan secara in vitro adalah jumlah sampel yang diperlukan sedikit, biaya lebih murah, dapat menentukan kecernaan berbagai jenis sampelpakan dalam waktu yang relatif singkat (96 jam), dapat dipelajari proses fermentasi yang terjadi di dalam rumen dan aktivitas mikroba tanpa dipengaruhi oleh induk semang dan pakannya, serta hasilnya mempunyai korelasi positif dengan dengan kecernaan secara in vivo. Adapun kelemahan teknik in vitro adalahpopulasi mikroba dalam tabung fermentor selama masa inkubasi sulit terjaga.

Pada teknik in vitro salah satu bahan yang digunakan adalah larutan saliva atau larutan McDougall. Larutan ini berfungsi sebagai pengatur kestabilan $\mathrm{pH}$ selama proses fermentasi berlangsung. Para peneliti menggunakan larutan McDougall dicampur dengan cairan rumen dengan rasio 4 : 1 (Tilley dan Terry, 1963; Moore, 1970; Harris, 1970), 2 : 1 (Menke dan Steingass, 1988), 1 : 2 (Mauricio et al., 2001), 3 : 2 (Minson dan McLeod, 1972), dan 5 : 1 (El-Meadaway et al., 1988) sebagai medium inkubasi. Ini menunjukkan para peneliti menggunakan rasio larutan McDougall dengan cairan rumen pada level yang berbeda dalam pengujian kecernaan suatu bahan pakan sehingga diperoleh nilai kecernaan suatu bahan pakan yang berbeda pula.

Selain rasio cairan rumen dengan larutan McDougall, kita ketahui yang menjadi sumber mikroba dalam teknik in vitro adalah cairan rumen sapi. Selain cairan rumen sapi, cairan rumen kerbau juga dapat dijadikan sebagai sumber mikroba. Menurut Van Soest (1994) kerbau dan sapi termasuk golongan ruminansia. Di dalam rumennya terdapat berbagai spesies dan jenis mikrobia.

Pakan kerbau dan sapi pada umumnya berupa rumput. Kerbau lebih banyak mengkonsumsi rumput daripada sapi. Hal ini disebabkan volume saluran pencernaan kerbau lebih besar, sehingga total koloni mikroba cairan rumen kerbau lebih banyak daripada total koloni mikroba yang terdapat dalam cairan rumen sapi. Pradhan (1994) melaporkan bahwa total bakteri asal cairan rumen kerbau adalah $16,20 \times 10^{8} \mathrm{CFU} / \mathrm{ml}$ sedangkan yang berasal dari cairan rumen sapi adalah 13,20 x $10^{8} \mathrm{CFU} / \mathrm{ml}$. Selanjutnya menurut Surhayadi (1996) aktivitas bakteri selulolitik asal cairan rumen kerbau lebih tinggi daripada yang berasal dari cairan rumen sapi. Dengan demikian kerbau lebih potensial menjadi donor inokulan untuk analisis kecernaan pakan secara in vitro. Hal tersebut berbeda dengan pernyataan Puppo et al. (2002) yang melaporkan bahwa kemampuan mikroba rumen sapi 
dalam mendegradasi bahan organik dan selulosa lebih baik dari pada mikroba rumen kerbau.

Dari uraian diatas ditemukan dua permasalahan, yang pertama bahwa selama ini para peneliti menggunakan level larutan McDougall yang berbeda-beda dalam melakukan analisis in vitro, dan yang kedua adalah adanya perbedaan asumsi tentang kualitas cairan rumen sapi dan cairan rumen kerbau sebagai sumber mikroba dalam teknik in vitro. Dengan demikian akan menjadi sesuatu hal yang positif jika dilakukan penelitian tentang kombinasi rasio larutan McDougall dengan cairan rumen dan asal cairan rumen terhadap kecernaan bahan kering, bahan organik, dan protein kasar secara in vitro.

Penelitian ini bertujuan untuk mengetahui pengaruh berbagai level larutan McDougall, asal cairan rumen, dan kombinasi berbagai level larutan McDougall dengan asal cairan rumen terhadap kecernaan bahan kering, bahan organik, dan protein kasarsecara in vitro. Hasil penelitian ini diharapkan dapat dijadikan sebagai informasi dan pedoman dalam menggunakan rasio cairan rumen dengan larutan McDougall dan dapat diketahuinya asal cairan rumen yang terbaik dalam teknik in vitro.

\section{MATERI DAN METODE}

Bahan yang digunakan dalam penelitian ini yaitu rumput Kumpai, cairan rumen sapi dan kerbau yang berasal dari Rumah Potong Hewan Jambi, reagent yang digunakan terdiri: Sodium Bicarbonate
$\left(\mathrm{NaHCO}_{3}\right)$, Sodium Hidrogen Posfat $\left(\mathrm{NaHPO}_{4}, 7 \mathrm{H}_{2} \mathrm{O}\right)$, Potasium Klorida $(\mathrm{KCl})$, Sodium Klorida $(\mathrm{NaCl})$, Magnesium Sulfat $\left(\mathrm{MgSO}_{4}, 7 \mathrm{H}_{2} \mathrm{O}\right)$, Kalsium Klorida $\left(\mathrm{CaCl}_{2}\right)$, $\mathrm{HCl}$ 0,1 N, Pepsin, $\mathrm{HCl} 0,1 \mathrm{~m}$, Aquades, $\mathrm{HgCl}_{2}$ jenuh, dan $\mathrm{Gas} \mathrm{CO}_{2}$.

Alat yang digunakan terdiri atas botol fermentor $160 \mathrm{ml}$ dengan penutup karet dan alumunium, clamper dan declamper, aqua shaker, glass syringe, neraca analitik, oven $105^{\circ} \mathrm{C}$, tanur, cawan porselin, desikator, 2 termos air, labu ukur $1000 \mathrm{ml}$ dan glass piala $2500 \mathrm{ml}$, kain kasa, corong plastik, gelas piala, corong buchner, pompa vakum, pemanas listrik, penjepit, kertas saring No. 41, labu destruksi, lemari asam, destilator, dan beker glass.

\section{Rancangan Percobaan}

Rancangan percobaan yang digunakan dalam penelitian ini adalah Rancangan Acak Lengkap dua arah (RAL Faktorial) yang terdiri dari faktor A dan faktor B. Faktor A adalah rasio McDougall dengan cairan rumen yaitu A1 (2:1), A2 (3:1), dan A3 (4:1). Faktor B adalah asal cairan rumen yaitu B1 (cairan rumen sapi) dan B2 (cairan rumen kerbau). Dengan demikian terbentuk 6 kombinasi perlakuan dengan 4 ulangan. Susunan perlakuan yang dicobakan pada penelitian ini adalah sebagai berikut:

A1B1 = 2:1 (26,67 ml larutan McDougall :

$$
13,33 \mathrm{ml} \text { cairan rumen sapi) }
$$

A1B2 $=2: 1(26,67 \mathrm{ml}$ larutan McDougall :

$$
13,33 \mathrm{ml} \text { cairan rumen kerbau) }
$$

A2B1 = 3:1 (30 ml larutan McDougall : 10 $\mathrm{ml}$ cairan rumen sapi) 
$\mathrm{A} 2 \mathrm{~B} 2=3: 1(30 \mathrm{ml}$ larutan McDougall : 10 $\mathrm{ml}$ cairan rumen kerbau)

A3B1 = 4:1 (32 ml larutan McDougall : 8 $\mathrm{ml}$ cairan rumen sapi)

A3B2 $=4: 1(32 \mathrm{ml}$ larutan McDougall $: 8$ $\mathrm{ml}$ cairan rumen kerbau)

Model matematika dari rancangan yang digunakan pada percobaan ini adalah :

$$
Y i j k=\mu+\alpha i+\beta j+(\alpha \beta) i j+€ i j k
$$

\section{Persiapan Sampel Rumput Kumpai}

Rumput Kumpai diambil, kemudian dipotong-potong dengan panjang $\pm 2 \mathrm{~cm}$. Rumput Kumpai yang telah dipotong-potong kemudian dikeringkan dalam oven dengan temperatur 50-60 ${ }^{\circ} \mathrm{C}$ selama 24 - 48 jam. Setelah kering, kemudian digiling dengan menggunakan hammer mill selanjutnya diayak dengan ukuran pori-pori ayakan \pm 2 $\mathrm{mm}$ untuk diinkubasi secara in vitro. Sebelum diinkubasi, sebagian dari sampel rumput Kumpai tersebut dianalisis nilai bahan kering, bahan organik, dan protein kasar.

\section{Prosedur Kerja Penentuan Kecernaan secara In Vitro (Chuzaemi et al., 1983)}

\section{Persiapan 1 Liter Larutan McDougall}

Langkah pertama ditimbang dengan akurat : 9,8 gram $\mathrm{NaHCO}_{3}, 10$ gram $\mathrm{Na}_{2} \mathrm{HPO}_{4} 12 \mathrm{H}_{2} \mathrm{O}, 0,57$ gram $\mathrm{KCl}$, 0,47 gram $\mathrm{NaCl}, 0,12$ gram $\mathrm{MgSO}_{4} 7 \mathrm{H}_{2} \mathrm{O}$. Selanjutnya dilarutkan dengan $500 \mathrm{ml}$ aquades di dalam glass piala (kapasitas $1000 \mathrm{ml}$ ) (Larutan 1). Pelarutan dilakukan pada suhu $39^{\circ} \mathrm{C}$ dan menggunakan magnetic stirer untuk mempercepat proses. Selanjutnya 5,3 gram $\mathrm{CaCl}_{2}$ ditimbang dengan akurat kemudian dimasukkan ke dalam gelas ukur dan dilarutkan dengan $100 \mathrm{ml}$ aquades (Larutan 2). Selanjutnya 1 ml Larutan 2 ditambahkan ke dalam Larutan 1. Kemudian aduk hingga homogen (Larutan 3). Selanjutnya aquades ditambahkan ke dalam Larutan 3 hingga volume menjadi $1000 \mathrm{ml}$, maka terbentuklah 1 Liter larutan McDougall. Untuk menetralkan $\mathrm{pH}$, ke dalam larutan ditambahkan $\mathrm{HCl}$ 0,1 m. Larutan $\mathrm{HCl}$ 0,1 $\mathrm{m}$ dipersiapkan dengan cara mengencerkan $455,75 \mathrm{ml} \mathrm{HCl}$ pekat (normalitas 11,3) dengan 44,25 $\mathrm{ml}$ aquades.

\section{Persiapan Inokulan}

Pertama, 2 buah termos diisi air panas pada suhu $39-40^{\circ} \mathrm{C}$. Selanjutnya, Digesta (bolus) diambil dari berbagai bagian dalam rumen sapi dan kerbau yang telah dipotong di RPH, kemudian disaring dengan 2 lapis kain kasa dan dimasukkan ke dalam termos yang sudah dibuang airnya. Terakhir, cairan rumen segera dibawa ke Laboratorium.

\section{Pembuatan Larutan HCl Pepsin}

Larutan pepsin dibuat dengan melarutkan 0,2 gram pepsin dengan $0,1 \mathrm{~N}$ $\mathrm{HCl}$ menjadi $50 \mathrm{ml}$.

\section{Pelaksanaan Proses Pencernaan secara Fermentatif}

Larutan McDougall dimasukkan ke dalam beaker glass (disesuaikan dengan perlakuan) dan dijaga temperaturnya \pm $39^{\circ} \mathrm{C}$. Cairan rumen ditambahkan ke dalam 
beaker glass (disesuaikan dengan perlakuan) yang telah berisi larutan McDougall, kemudian diaduk dengan electric stirrer dengan tetap menjaga temperatur di $39^{\circ} \mathrm{C}$. Rumen buatan yang telah terbentuk tadi, disamping diaduk dengan electric stirrer juga dialiri gas $\mathrm{CO}_{2}$ agar mendapatkan kondisi yang anaerob. Selanjutnya ke dalam botol fermentor yang telah diisi sampel rumput Kumpai sebanyak 0,5 gram, ditambahkan campuran larutan McDougall dan cairan rumen sesuai dengan perlakuan, kemudian dialiri gas $\mathrm{CO}_{2}$ selama 15 detik lalu ditutup dengan karet dan dengan penutup alumunium, kemudian diinkubasi di dalam inkubator pada temperatur $\pm 39^{\circ} \mathrm{C}$ selama 48 jam. Setiap 2 jam sekali botol-botol fermentor tersebut digoyang secara manual untuk mendapatkan kondisi gerakan seperti di dalam rumen. Setelah 48 jam, ke dalam masing-masing tabung fermentor ditambahkan $\mathrm{HgCl}_{2}$ jenuh \pm 1 -2 tetes yang bertujuan untuk menghentikan aktivitas mikroba rumen. Selanjutnya sampel dalam tabung fermentor dipindahkan ke dalam tabung sentrifuge dan disentrifuge dengan kecepatan 2000 rpm selama 15 menit. Setelah 15 menit disentrifuge, kemudian cairan supernatant dibuang dengan hatihati (sampel masih berada dalam tabung sentrifuge).

\section{Tahap Proses Pencernaan secara Hidrolisis}

Pada tahap pencernaan secara hidrolisis ini, sampel yang ada di dalam tabung sentrifuge dipindahkan kembali ke dalam tabung fermentor kemudian ditambah dengan $40 \mathrm{ml}$ larutan $0,2 \%$ pepsin $0,1 \mathrm{~N} \mathrm{HCl}$, dan diinkubasi kembali dalam inkubator pada temperatur $39^{\circ} \mathrm{C}$ selama 48 jam dan dalam kondisi aerobik. Setelah 48 jam, tabung-tabung fermentor dikeluarkan dari inkubator dan cairan supernatant dibuang dengan memakai filter stick yang dihubungkan dengan pompa penghampa air serta mencucinya dengan air destilasi. Kemudian sampel dikeringkan dalam oven pada temperatur $60^{\circ} \mathrm{C}$ selama 24 jam, kemudian dimasukkan ke dalam desikator selama 1 jam baru kemudian ditimbang. Untuk mengetahui persentase bahan keringnya, sampel tersebut kemudian di oven kembali pada suhu $105^{\circ} \mathrm{C}$ selama 4 jam, kemudian didinginkan di desikator selama 1 jam dan ditimbang. Untuk mengetahui persentase bahan organik, sampel masing-masing perlakuan dimasukkan ke dalam tanur pada suhu $600^{\circ} \mathrm{C}$ selama 4 jam. Setelah itu didinginkan di dalam desikator kemudian ditimbang. Untuk mengetahui kandungan protein kasarnya, sampel masing-masing perlakuan didestruksi kemudian didestilasi, dan terakhir dititrasi sehingga dapat diketahui kandungan protein kasarnya.

\section{Pengambillan Data sesuai Parameter}

Peubah yang diamati dalam penelitian ini adalah sebagai berikut :

Kecernaan Bahan Kering (KcBK)

$\operatorname{KcBK}(\%)=\frac{(\text { BKA }- \text { BKR }- \text { Blanko } \times 100 \%}{\text { BKA }}$ 
Kecernaan Bahan Organik (KcBO)

$$
\mathrm{KcBO}(\%)=\frac{(\mathrm{BOA}-\mathrm{BOR}-\mathrm{Blanko}) \times 100 \%}{\text { BOA }}
$$

Kecernaan Protein Kasar (KcPK)

KcPK $(\%)=(\underline{\text { PKA }- \text { PKR }-(\text { Blanko }) \times 100 \%}$ PKA

Keterangan :

BKA $=$ Bahan kering awal

$\mathrm{BKR}=$ Bahan kering residu

$\mathrm{BOA}=$ Bahan organik awal

$\mathrm{BOR}=$ Bahan organik residu

$\mathrm{PKA}=$ Protein kasar awal

$\mathrm{PKR}=$ Bahan organik residu

\section{Analisis Data}

Data yang diperoleh dari penelitian ini diolah dengan menggunakan Analisis
Ragam. Jika terdapat pengaruh yang nyata dilanjutkan dengan uji jarak Duncan (Steel dan Torrie, 1993).

\section{HASIL DAN PEMBAHASAN}

\section{Kecernaan Bahan Kering (KcBK)}

Kecernaan bahan kering merupakan salah satu indikator untuk menentukan kualitas pakan. Semakin tinggi kecernan bahan kering maka zat-zat makanan yang dapat digunakan untuk memenuhi kebutuhan nutrisi ternak juga semakin tinggi (Sutardi, 1979). Berikut ini rataan kecernaan bahan kering rumput Kumpai pada berbagai level larutan McDougall dan asal cairan rumen terlihat pada Tabel 1.

Tabel 1. Rataan kecernaan bahan kering rumput kumpai pada berbagai level larutan Mcdougall dan asal cairan rumen (\%)

\begin{tabular}{cccc}
\hline \multirow{2}{*}{$\begin{array}{c}\text { McDougall } \\
\text { Cairan Rumen }\end{array}$} & \multicolumn{2}{c}{ Asal Cairan Rumen (B) } & \\
\cline { 2 - 3 } (A) & Cairan Rumen & $\begin{array}{c}\text { Cairan Rumen } \\
\text { Kerbau }\end{array}$ & Rataan (A) \pm SD \\
\hline $2: 1$ & Sapi & $48,34 \pm 4,53$ & $46,53 \pm 2,55$ \\
$3: 1$ & $44,73 \pm 9,74$ & $46,45 \pm 4,44$ & $44,49 \pm 2,76$ \\
$4: 1$ & $47,19 \pm 6,72$ & $45,57 \pm 0,25$ & $46,38 \pm 1,15$ \\
\hline Rataan (B) \pm SD & $44,82 \pm 2,33$ & $46,79 \pm 1,42$ & $45,81 \pm 1,39$ \\
\hline
\end{tabular}

Hasil analisis ragam menunjukkan bahwa level larutan McDougall dan asal cairan rumen tidak berpengaruh nyata ( $P>0,05)$ terhadap kecernaan bahan kering dan tidak terdapat interaksi $(\mathrm{P}>0,05)$ antara level larutan McDougall dan asal cairan rumen. Hal ini tidak berdampak negatif, artinya adalah bahwa kombinasi antara level larutan McDougall dengan cairan rumen sapi dan kombinasi antara larutan McDougall dan cairan rumen kerbau mampu menunjukkan kecernaan bahan kering. Menurut Anggorodi (1994) kecernaan merupakan indikasi yang penting untuk diketahui, sebab kecernaan dapat digunakan sebagai petunjuk tentang pemanfaatan pakan oleh ternak atau menentukan jumlah nutrien dari bahan pakan yang mampu diserap oleh saluran pencernaan.

Dari Tabel 1 terlihat bahwa rataan kecernaan bahan kering pada berbagai 
level larutan McDougall dan asal cairan rumen secara statistik relatif sama. Hal ini diduga mikroba yang berasal dari cairan rumen sapi dan juga cairan rumen kerbau mampu menunjukkan aktivitas yang sama, baik pada level $2: 1,3: 1$, maupun $4: 1$. Menurut Preston dan Leng (1987) cairan rumen dihuni tidak kurang dari empat jenis mikroba yaitu : bakteri, protozoa, fungi dan virus atau bakteriophage. Selanjutnya Thalib et al. (2000) melaporkan bahwa semua bakteri yang berasal dari cairan rumen sapi dan kerbau yang telah diadaptasi pada hemiselulosa, selulosa, dan hemiselulosa memperlihatkan keragaman spesies bakteri yang hampir sama. Ini berarti mikroba yang berasal dari cairan rumen sapi dan cairan rumen kerbau akan mensekresikan enzim yang sama untuk mencerna bahan kering rumput Kumpai.

Peningkatan volume larutan McDougall pada setiap level $(2: 1,3: 1$, dan $4: 1$ ) juga menunjukkan kecernaan bahan kering yang relatif sama. Hal ini diduga penambahan larutan McDougall tidak berdampak negatif pada aktivitas mikroba selama masa inkubasi secara fermentatif. Artinya meskipun penambahan larutan McDougall pada $2: 1$, $3: 1$ dan $4: 1$ menyebabkan perubahan $\mathrm{pH}$ (Lampiran 4), namun $\mathrm{pH}$ tersebut masih berada pada kisaran yang optimal untuk aktivitas mikroba. Misalnya untuk enzim selulase yang dihasilkan oleh mikroba pencerna selulosa asal cairan rumen akan beraktivitas secara optimal pada $\mathrm{pH} 4$ (Budiansyah, 2010). Dengan demikian ada keterkaitan antara $\mathrm{pH}$ dengan aktivitas enzim yang dihasilkan oleh mikroba. Kelemahan dari penelitian ini adalah tidak diukur $\mathrm{pH}$ pada akhir inkubasi secara fermentatif, sehingga pada pembahasan ini sulit dijelaskan keterkaitan antara perubahan $\mathrm{pH}$ akibat peningkatan volume larutan McDougall pada berbagai level dengan aktivitas mikroba yang berasal dari cairan rumen sapi dan kerbau.

\section{Kecernaan Bahan Organik (KcBO)}

Sama halnya dengan kecernaan bahan kering, kecernaan bahan organik juga merupakan salah satu indikator untuk menentukan kualitas pakan. Rataan kecernaan bahan organik dapat dilihat pada Tabel 2.

Tabel 2. rataan kecernaan bahan organik rumput kumpai pada berbagai level larutan Mcdougall dan asal cairan rumen (\%)

\begin{tabular}{cccc}
\hline \multirow{2}{*}{$\begin{array}{c}\text { McDougall : } \\
\text { Cairan Rumen (A) }\end{array}$} & Cairan Rumen Sapi & $\begin{array}{c}\text { Cairan Rumen } \\
\text { Kerbau }\end{array}$ & Rataan (A) \pm SD \\
& $42,00 \pm 10,24$ & $46,29 \pm 4,23$ & $44,15 \pm 3,03$ \\
$3: 1$ & $37,71 \pm 4,40$ & $43,27 \pm 4,94$ & $40,49 \pm 3,93$ \\
$4: 1$ & $43,51 \pm 7,73$ & $42,27 \pm 1,02$ & $42,89 \pm 0,88$ \\
\hline Rataan (B) \pm SD & $41,07 \pm 3,01$ & $43,95 \pm 2,09$ & $42,51 \pm 2,03$ \\
\hline Hasil analisis ragam menunjukkan & cairan rumen tidak berpengaruh nyata & \\
bahwa level larutan & McDougall dan asal & $(\mathrm{P}>0,05)$ & terhadap kecernaan bahan
\end{tabular}


organik dan tidak terdapat interaksi $(\mathrm{P}>0,05)$ antara level larutan McDougall dan asal cairan rumen. Pada Gambar 1

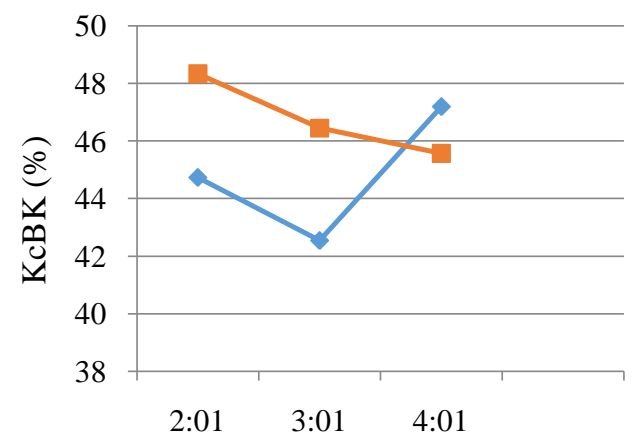

berikut dapat dilihat pola kecernaan bahan organik dan bahan kering.

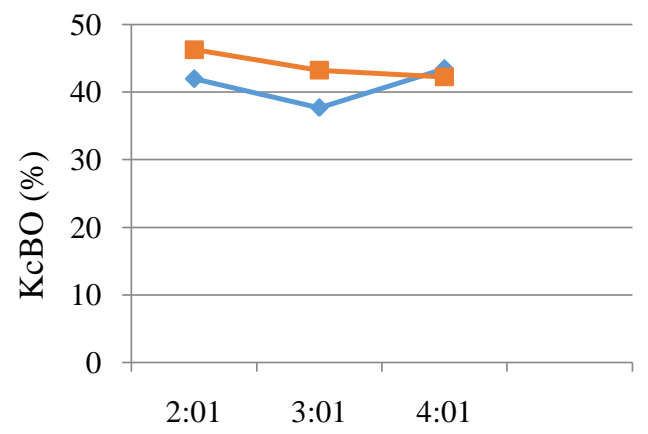

Larutan McDougall : Cairan Rumen (ml)

Gambar 1. Kecernaan Bahan Kering dan Bahan Organik pada Kombinasi Larutan McDougall dengan Cairan Rumen Sapi $(\forall)$ dan Kombinasi Larutan McDougall dengan Cairan Rumen Kerbau ( $\square)$

Pada Gambar 1 terlihat bahwa pola kecernaan bahan organik sama dengan pola kecernaan bahan kering. Hal ini sesuai dengan pernyataan Tillman et al. (1990) bahwa pola dari kecernaan bahan organik sejalan dengan kecernaan bahan kering, karena sebagian besar dari bahan kering terdiri dari bahan organik (Anggorodi, 1994) dan yang membedakannya adalah abu (Sutardi, 1978).

Hasil penelitian ini sejalan dengan hasil penelitian yang dilakukan oleh Sudirman et al. (2006) yang melaporkan bahwa rasio 2 : 1 (saliva buatan : feses kerbau) mampu menunjukkan kecernaan bahan organik yang relatif lebih tinggi daripada rasio $4: 1$, serta sesuai kisaran hasil penelitian Akhter dan Hosain (1998), Mauricio et al. (2001), dan Thu (2003).

\section{Kecernaan Protein Kasar (KcPK)}

Rataan kecernaan protein kasar rumput Kumpai pada berbagai level larutan McDougall dan asal cairan rumen dapat dilihat pada Tabel 3 berikut. Hasil analisis ragam menunjukkan bahwa level larutan McDougall (Faktor A) berpengaruh nyata $(\mathrm{P}<0,05)$ terhadap kecernaan protein kasar. Namun faktor asal cairan rumen (Faktor B) tidak berpengaruh nyata terhadap kecernaan protein kasar dan tidak terdapat interaksi $(\mathrm{P}>0,05)$ antara level larutan McDougall dan asal cairan rumen.

Dari hasil uji lanjut pada Tabel 3 di atas dapat dilihat bahwa rataan kecernaan protein kasar pada level larutan McDougall $4: 1$ (A3) tidak berbeda nyata $(\mathrm{P}>0,05)$ dibandingkan dengan level McDougall 2 : 1 (A1) dan nyata lebih tinggi $(\mathrm{P}<0,01)$ dibandingkan dengan level McDougall 3 : 1 (A2). Sedangkan rataan kecernaan protein kasar pada level larutan McDougall 2 : 1 (A1) nyata lebih tinggi $(\mathrm{P}<0,01)$ dibandingkan dengan level larutan McDougall 3 : 1 (A2). 
Tabel 3. Rataan kecernaan protein kasar rumput kumpai pada berbagai level larutan McDougall dan asal cairan rumen $(\%)$

\begin{tabular}{cccc}
\hline \multirow{2}{*}{$\begin{array}{c}\text { McDougall: Cairan } \\
\text { Rumen (A) }\end{array}$} & \multicolumn{2}{c}{ Asal Cairan Rumen (B) } & \\
\cline { 2 - 3 } & $\begin{array}{c}\text { Cairan Rumen } \\
\text { Sapi }\end{array}$ & $\begin{array}{c}\text { Cairan Rumen } \\
\text { Kerbau }\end{array}$ & Rataan (A) \pm SD \\
\hline $2: 1$ & $62,01 \pm 6,69$ & $64,56 \pm 3,11$ & $63,29^{\mathrm{a}} \pm 1,80$ \\
$3: 1$ & $56,95 \pm 2,94$ & $56,56 \pm 3,60$ & $56,76^{\mathrm{b}} \pm 0,28$ \\
$4: 1$ & $63,69 \pm 4,62$ & $59,20 \pm 0,18$ & $61,45^{\mathrm{a}} \pm 3,17$ \\
\hline Rataan (B) \pm SD & $60,89 \pm 3,51$ & $60,12 \pm 4,08$ & $60,49 \pm 0,55$ \\
\hline
\end{tabular}

$\overline{\mathrm{a}, \mathrm{b}}$,rataan dengan superskrip yang berbeda pada kolom yang sama menunjukkan perbedaan yang nyata $(\mathrm{P}<0,05)$

Hasil uji lanjut tersebut menunjukkan bahwa level larutan McDougall berpengaruh nyata terhadap kecernaan protein kasar. Larutan McDougall pada level $4: 1$ menunjukkan pertumbuhan mikroba yang optimum. Begitu pula pada larutan McDougall pada level 2 : 1 , sehingga kecernaan protein kasar nyata lebih tinggi daripada larutan McDougall pada level $3: 1$. Situasi ini selain dipengaruhi oleh komposisi pakan (kadar protein), sumber inokulan (Johnson, 1996), kemampuan mikroba rumen mencerna pakan dan $\mathrm{pH}$, juga diduga dipengaruhi oleh protein yang berasal dari mikroba, baik mikroba pada cairan rumen sapi maupun cairan rumen kerbau. Hal ini sebagaimana dijelaskan oleh Hoover and Stokes (1991) bahwa mikroba rumen merupakan sumber utama asam amino pada ternak ruminansia. Hampir dua pertiga dari asam amino yang diserap oleh ternak ruminansia berasal dari mikroba rumen.

Untuk lebih jelas mengenai kecernaan protein kasar rumput Kumpai pada berbagai level larutan McDougall dan asal cairan rumen dapat dilihat pada Gambar 2.

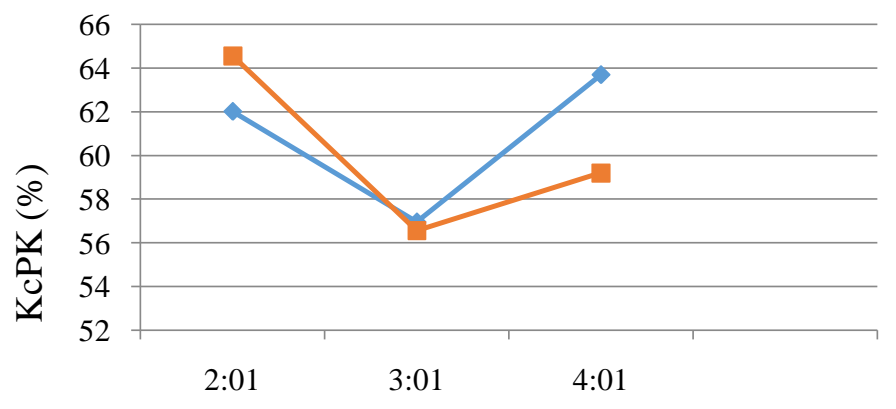

Larutan McDougall : Cairan Rumen (ml)

Gambar 2. Kecernaan protein kasar pada kombinasi larutan McDougall dengan cairan rumen $\operatorname{sapi}(\forall)$ dan kombinasi larutan McDougall dengan cairan rumen kerbau $(\square)$

Pada Gambar 2 terlihat bahwa penambahan larutan McDougall pada level
$2: 1$ dan $4: 1$ menunjukkan kecernaan protein kasar yang lebih tinggi daripada 
3 : 1. Selanjutnya 2: 1 menunjukkan kecernaan protein kasar yang lebih tinggi daripada $4: 1$. Hal ini selain faktor $\mathrm{pH}$ dan mikroba rumen, juga dipengaruhi oleh faktor kepadatan optimal populasi mikroba $\left(7,7 \pm 1,40 \times 10^{6} \mathrm{CFU} /\right.$ mililiter $)$ dalam medium inkubasi (Sudirman et al., 2006).

\section{KESIMPULAN}

Berdasarkan hasil penelitian ini, dapat disimpulkan bahwa secara statistik penggunaan berbagai level larutan McDougall yang dikombinasikan baik dengan cairan rumen sapi maupun cairan rumen kerbau menunjukkan kecernaan bahan kering dan bahan organik yang relatif sama. Namun pada level 2 : 1 (McDougall : cairan rumen) memberikan pengaruh yang nyata lebih tinggi terhadap kecernaan protein kasar.

\section{DAFTAR PUSTAKA}

Akhter, S. and M. M. Hossain. 1998. Cow Faces in In Vitro Digetibility Assay of Forage. Aust. J. Anim. Sci. 11 (1): 51-54.

Anggorodi, R. 1994. Ilmu Makanan Ternak Umum. Gramedia. Jakarta .

Budiansyah, A. 2010. Aplikasi Cairan Rumen Sapi sebagai Sumber Enzim, Asam Amino, Mineral dan Vitamin pada Ransum Broiler Berbasis Pakan Lokal. Disertasi. Institut Pertanian Bogor. Bogor.
Chuzaemi, S., Hartutik, dan S. Susanto. 1983. Petunjuk Analisa Bahan Makanan Ternak. Nuffic-Unibraw. Bagian Ilmu Makanan Ternak. Fakultas Peternakan. Universitas Brawijaya. Malang.

El-Meadaway, A., Z. Mir, P. S. Mir, M. S. Zaman and L. J. Yanke. 1988. Relative efficacy of Inocula from Rumen fluid or faecal solution for determining In Vitro digestibility and gas production. Can. J. Anim. Sci. 78: 673-679.

Harris, L. E. 1970. Nutrition Research Techniques for Domestic and Wild Animal. Volume 1. An International Record System and Procedures for Analyzing Sample.

Hoover, W. H. and S. R. Stokes. 1991. Balancing carbohydrates and proteins for optimum Rumen microbial yield. J. Dairy Sci. 74: 3630 .

Mauricio, R. M., E. Owen, F. L. Mould, I. Givens, M. K. Theodorou, J. France, D. R. Davies, and M. S. Dhanoa. 2001. Comparison of Bovine Rumen liquor and Bovine faeces as Inokulum for an In Vitro Gas production technique for evaluating for ages. Anim. Feed Sci. Technol. 89: 33-48.

Minson, D. J. and M. N. McLeod. 1972. The in Vitro Technique: its Modification for Number of Tropical Pasture Samples. 
Commonwealth Scintific and Industrial Research Organization , Australia.

Moore. J. E. 1970. Procedure for the TwoStage In Vitro Digestion of Forage. Department of Anim. Sci., University of Florida, USA.

Menke, K. H. and H. Steingass. 1988. Estimation of the energetic feed value obtained from chemical analysis and In Vitro Gas production using Rumen fluid. Anim. Res. Develop. 28:7-55.

Pradhan, K. 1994. Rumen Ecosystem in Relation to Cattle and Buffalo Nutrition. In: Wanapat, M. and K. Somniart (Editor). Proc. First Asian Buffalo Association Congress.

Preston, T. R and R. A. Leng. 1987. Matching Ruminant Production System with Available Resources in Tropic. Penambul Books, Armidale.

Puppo, S., S. Bartocci, S. Terramocci, F. Grandoni, and A. Amici. 2002. Rumen microbial counts and In Vitro digestibility in Buffaloes and Cattle given different diets. Animal Sci. 75: 323-329.

Steel, R. G. D. dan J. H. Torrie. 1933. Prinsip dan Prosedur. Statistika. Gramedia. Jakarta

Sudirman, R., Utomo, Z. Bachruddin, B. P. Widyobroto, dan Suhubdy. 2007. Kajian rasio inokulum feses
Kerbau/ Buffer (Saliva Buatan) pada analisis kecernaan pakan berserat secara In Vitro. J. Indon. Trop. Anim. Agric. 32 (1): 8.

Sutardi, T. 1979. Ketahanan Protein Bahan Makanan terhadap Degradasi Mikroba Rumen dan Manfaatnya bagi Peningkatan Produktivitas Ternak. Prosiding Seminar Penelitian dan Penunjang Peternakan. LPP Institut Pertanian Bogor. Bogor.

Sutardi, T. 1978. Ikhtisar Ruminologi. Departemen Makanan Ternak. Fakultas Peternakan. Institut Pertanian Bogor. Bogor.

Thalib, A., Y. Widiawati, H. Hamid, dan Mulyani. 2000. Identifikasi Morfologis dan Uji Aktivitas Mikroba Rumen dari HewanHewan Ruminansia yang Telah Teradaptasi pada Substrat Selulosa dan Hemiselulosa. Seminar Nasional Peternakan dan Veteriner. Bogor. Hal. 345-347.

Thu, N. V. 2003. Effect of Different Strategis of Processing Rice Straw on In Vitro Digestibility Using Rumen Fluid or Faecal Inocula of Local Cattle. In : R. Preston and B. Ogle (Ed.). Proceeding of Final National Seminar-Workshop on Sustainable Livestock Production on Local Feed Resources. HUAFSAREC, Hue City, 25-28 March 2003. 
Tilley , J. M. A, and R. A. Terry. 1963. A

Two Stage Technique for the In Vitro digestion of forage crop. Journal of British Grassland. 18 : $104-111$.

Tillman, A. P., H. Hartadi, S. Reksohadiprodjo, P. Suharto dan S.
Lebdosoekojo. 1990. Ilmu Makanan Ternak Dasar. Gadjah Mada University Press. Yogyakarta.

Van Soest, P. J. 1994. Nutritional Ecology of The Ruminant. ( $2^{\text {nd }}$ ed) Cornell University Press, USA. 476p. 